\section{PELAKSANAAN SANKSI BAGI PEJABAT NOTARIS BERDASARKAN UNDANG-UNDANG NOMOR 30 TAHUN 2004 TENTANG JABATAN NOTARIS ${ }^{1}$}

Oleh : Fransiscus Joel Robert Simarmata ${ }^{2}$

\begin{abstract}
ABSTRAK
Tujuan dilakukannya penelitian ini adalah untuk mengetahui apa saja yang menjadi larangan bagi pejabat notaris berdasarkan UndangUndang Nomor 30 Tahun 2004 dan bagaimana pelaksanaan sanksi bagi pejabat notaris berdasarkan Undang-Undang Nomor 30 Tahun 2004. Dengan menggunakan metode penelitian yuridis normatif, disimpulkan: 1. Laranganlarangan bagi pejabat notaris berdasarkan Undang-Undang Nomor 30 Tahun 2004 Tentang Jabatan Notaris terdapat dalam Pasal 17 Undang-Undang Jabatan Notaris yang dapat berupa menjalankan jabatan diluar wilayah jabatannya, meninggalkan wilayah jabatannya lebih dari 7 (tujuh) hari kerja berturut-turut tanpa alasan yang sah, merangkap sebagai pegawai negeri, pejabat negara, dan advokat, sebagai pemimpin atau pegawai badan usaha negara, badan usaha milik daerah, atau badan usaha swasta, sebagai pejabat pembuat akta tanah atau pejabat lelang kelas II diluar tempat kedudukan notaris serta menjadi notaris pengganti. 2. Pelaksanaan sanksi jabatan notaris tidak dijelaskan dalam Undang-Undang No. 30 Tahun 2004, namun dalam Pasal 89 Undang-Undang ini menjelaskan bahwa pada saat undang-undang ini mulai berlaku, kode etik notaris yang sudah ada tetap berlaku sampai ditetapkan kode etik notaris yang baru berdasarkan Undang-Undang Jabatan Notaris, dalam pasal tersebut mengisyaratkan bahwa dalam penerapan sanksi notaris juga termasuk dan berhubungan antara Undang-Undang Nomor 30 Tahun 2004 dan kode etik notaris. Pemberian sanksi berupa pemberhentian seorang notaris, dibagi menjadi 3 (tiga) kategori, yaitu: Pemberhentian Sementara, Pemberhentian dengan Hormat dan Pemberhentian dengan tidak Hormat.

Kata kunci: Pelaksanaan Sanksi, Pejabat Notaris, Jabatan Notaris
\end{abstract}

\footnotetext{
${ }^{1}$ Artikel Skripsi. Dosen Pembimbing: Prof. Dr. Wulanmas

A. P. G Frederik, SH, MH; Refly R. Umbas, SH, MH

${ }^{2}$ Mahasiswa pada Fakultas Hukum Unsrat, NIM.

16071101086
}

\section{PENDAHULUAN}

\section{A. Latar Belakang Masalah}

Notaris merupakan pejabat umum (publik) yang berwenang untuk membuat akta otentik, sejauh pembuatan akta otentik tertentu tidak dikhususkan bagi pejabat umum lainnya. Penegasan notaris sebagai pejabat publik yang berwenang membuat akta otentik ditemukan dalam Pasal 1 angka 1 revisi Undang-Undang Nomor 30 Tahun 2004 tentang Jabatan Notaris (UUJN). Pasal tersebut menegaskan: "Notaris adalah pejabat umum yang berwenang untuk membuat akta otentik dan memiliki kewenangan lainnya sebagaimana dimaksud dalam Undang-Undang ini atau berdasarkan Undang-Undang lainnya". 3

Notaris juga berkewajiban untuk memberikan nasihat hukum kepada para pihak, hal ini menjamin bahwa para pihak mengetahui apa yang menjadi keinginannya, tertuang dalam kontrak. Kehadiran dan keberadaan notaris adalah sebagai penengah yang tidak boleh berpihak, bukan sebagai perantara atau pembela ${ }^{4}$

Melaksanakan tugas jabatannya seorang notaris harus berpegang teguh kepada kode etik jabatan notaris, karena tanpa itu harkat dan martabat profesionalisme akan hilang dan tidak lagi mendapat kepercayaan dari masyarakat. $^{5}$

Notaris dan produk aktanya dapat dimaknai sebagai upaya negara untuk menciptakan kepastian dan perlindungan hukum bagi anggota masyarakat. Mengingat dalam wilayah hukum privat/perdata, negara menempatkan notaris sebagai pejabat umum yang berwenangan dalam hal pembuatan akta otentik, untuk kepentingan pembuktian/alat bukti. Hukum Positif di Indonesia telah mengatur jabatan notaris dalam suatu undangundang khusus yakni Undang-Undang No. 30 Tahun 2004 tentang Jabatan Notaris (UUJN).

Jabatan yang diemban notaris adalah suatu jabatan kepercayaan yang diberikan oleh undang-undang dan masyarakat, untuk itulah

\footnotetext{
${ }^{3}$ Abdul Ghofur Anshori, Lembaga Kenotariatan Indonesia, Yogyakarta, UI Press, 2009, hal. 13

4Tan Thong Kie, Studi Notariat, Serba-serbi praktek Notaris, Ichtiar Baru Van Hoeve, Jakarta, 2007, HIm. 519520.

${ }^{5}$ Komar Andasasmita, 1981, Notaris Dengan Sejarah, Peranan, Tugas Kewajiban, Rahasia Jabatannya, Sumur, Bandung, hlm.14
} 
seorang notaris bertanggung jawab untuk melaksanakan kepercayaan yang diberikan kepadanya. Notaris dengan selalu menjunjung tinggi etika hukum dan martabat serta keluhuran jabatannya, sebab apabila hal tersebut diabaikan oleh seorang notaris maka dapat menimbulkan kerugian bagi masyarakat umum dan mengganggu proses penegakan hukum yang sedang gencar dilakukan selama orde reformasi khususnya beberapa tahun terakhir.

Berdasarkan uraian diatas, maka penulis tertarik untuk membuat karya tulis ilmiah dalam bentuk skripsi yang berjudul : Pelaksanaan Sanksi bagi Pejabat Notaris berdasarkan Undang-Undang No.30 Tahun 2004 tentang Jabatan Notaris.

\section{B. Rumusan Masalah}

1. Apa saja yang menjadi larangan bagi pejabat notaris berdasarkan UndangUndang Nomor 30 Tahun 2004?

2. Bagaimana pelaksanaan sanksi bagi pejabat notaris berdasarkan UndangUndang Nomor 30 Tahun 2004?

\section{Metode Penelitian}

Ruang lingkup penelitian ini ialah pada disiplin ilmu hukum, maka penelitian ini merupakan bagian dari penelitian hukum kepustakaan yakni dengan "cara meneliti bahan pustaka atau yang dinamakan penelitian hukum normatif. ${ }^{6}$ Jenis penelitian dalam penelitian ini yaitu bersifat normatif, atau disebut juga dengan penelitian normatif.

\section{PEMBAHASAN}

\section{A. Larangan - Larangan bagi Pejabat Notaris berdasarkan Undang-Undang Nomor 30 Tahun 2004 Tentang Jabatan Notaris \\ Selain memiliki kewajiban, notaris} mempunyai larangan-larangan. Larangan menurut Kamus Besar Bahasa Indonesia, diartikan sebagai perintah (aturan) yang melarang suatu perbuatan. Adanya larangan bagi notaris dimaksudkan untuk menjamin kepentingan masyarakat yang memerlukan jasa notaris. $^{7}$

\footnotetext{
${ }^{6}$ Soerjono Soekanto dan Sri Mamudji., Penelitian Hukum Normatif Suatu Tinjauan Singkat., Jakarta 2004., Hal 14 ${ }^{7}$ Penjelasan pasal 17 Undang-Undang Nomor 30 Tahun 2004
}

Larangan bagi notaris dalam menjalankan jabatannya diatur dalam ketentuan Pasal 17 Undang-Undang Jabatan Notaris antara lain:

1. Menjalankan jabatan diluar wilayah jabatannya.

2. Meninggalkan wilayah jabatannya lebih dari 7 (tujuh) hari kerja berturutturut tanpa alasan yang sah.

3. Merangkap sebagai pegawai negeri.

4. Merangkap sebagai pejabat negara.

5. Merangkap jabatan sebagai advokat.

6. Merangkap jabatan sebagai pemimpin atau pegawai badan usaha milik negara, badan usaha milik daerah atau badan usaha swasta.

7. Merangkap jabatan sebagi pejabat pembuat akta tanah dan/atau pejabat lelang kelas II di luar tempat kedudukan notaris.

8. Menjadi notaris pengganti. Melakukan pekerjaan lain yang bertentangan dengan norma agama, kesusilaan, atau kepatutan yang dapat mempengaruhi kehormatan dan martabat jabatan notaris.

Pembatasan atau larangan bagi notaris ini ditetapkan untuk menjaga seorang notaris dalam menjalankan praktiknya bertanggung jawab terhadap segala hal yang dilakukannya. Tanpa adanya pembatasan, seseorang cenderung akan bertindak sewenang-wenang. Pemerintah membatasi wilayah kerja seorang notaris.

Undang-Undang Tentang Jabatan Notaris juga mengatur bahwa seorang notaris dilarang menjalankan jabatan di luar wilayah jabatannya. Sebagai contoh, seorang notaris yang memiliki wilayah kerja di Yogyakarta tidak dapat membuka praktik atau membuat akta otentik di wilayah Jakarta (batas yuridiksi notaris adalah provinsi).

Notaris dikenai sanksi jika meninggalkan wilayah jabatannya lebih dari tujuh hari kerja tanpa alasan yang sah. Seorang notaris tidak dapat seenaknya mengambil waktu untuk rehat karena tugas yang didelegasikan negara pada dirinya menuntut untuk senantiasa siap melayani mereka yang butuh pembuatan atau penetapan otentik tentang berbagai hal. Jika di suatu tempat tidak ada notaris lagi yang bertugas maka notaris yang berhalangan wajib menunjuk seorang notaris pengganti. 
Rangkap jabatan dapat membuat notaris tidak netral dan kehilangan fokus dalam melayani masyarakat dan akan lebih mendahulukan kepentingan pribadi atau kepentingan yang menguntungkan si notaris terlebih dahulu.

Secara singkat, menurut Ira Koesoemawati \& Yunirman Rijan, (2009:8) berikut adalah larangan bagi notaris: ${ }^{8}$

a. Notaris dilarang menjalankan jabatan di luar wilayah jabatannya.

b. Notaris dilarang meninggalkan wilayah jabatannya lebih dari tujuh hari kerja tanpa alasan yang sah.

c. Notaris dilarang melakukan rangkap jabatan dalam bentuk apa pun.

d. Notaris dilarang melanggar hukum yang berlaku di Indonesia.

Notaris hanya berkedudukan di satu tempat di kota/kabupaten, dan memiliki kewenangan wilayah jabatan seluruh wilayah provinsi dari tempat kedudukannya. Notaris hanya memiliki 1 kantor, tidak boleh membuka cabang atau perwakilan dan tidak berwenang secara teratur menjalankan jabatan dari luar tempat kedudukannya, yang artinya seluruh pembuatan akta harus sebisa mungkin dlaksanakan di kantor notaris kecuali pembuatan akta-akta tertentu. Notaris dapat membuat perserikatan perdata, dalam hal ini mendirikan kantor bersama notaris, dengan tetap memperhatikan kemandirian dan kenetralannya dalam menjalankan jabatan notaris. ${ }^{9}$

Larangan lainnya mengenai pejabat notaris adalah larangan untuk membuat akta untuk suami atau istri ataupun keluarga. Terdapat dalam Pasal 52 ayat (1) Undang-Undang No.30 Tahun 2004, yaitu :

Notaris tidak diperkenankan membuat akta untuk diri sendiri, istri/suami, atau orang lain yang mempunyai hubungan kekeluargaan dengan notaris baik karena perkawinan maupun hubungan darah dalam garis keturunan lurus ke bawah dan/atau ke atas

\footnotetext{
8 http://lib.ui.ac.id/file?file=digital/130992-T\%2027422Pengawasan\%20majelis-Analisis.pdf diakses pada tanggal 26 Oktober 2019 pukul 20.00

${ }^{9} \mathrm{https}$ ://birojasanotaris.com/info-notaris/laranganjabatan-notaris-menurut-uujn-pasal-17/ diakses tanggal 26 Oktober 2019 pukul 20.20
}

tanpa pembatasan derajat, serta dalam garis ke samping sampai dengan derajat ketiga, serta menjadi pihak untuk diri sendiri, maupun dalam suatu kedudukan ataupun dengan perantaraan kuasa.

Pembuatan akta untuk pihak-pihak yang disebutkan di atas oleh seorang notaris akan berakibat akta tersebut hanya mempunyai kekuatan pembuktian sebagai akta di bawah tangan apabila akta itu ditandatangani oleh penghadap, tanpa mengurangi kewajiban notaris yang membuat akta itu untuk membayar biaya, ganti rugi, dan bunga kepada yang bersangkutan. ${ }^{10}$

\section{B. Pelaksanaan Sanksi bagi Pejabat Notaris berdasarkan Undang-Undang Nomor 30 Tahun 2004 tentang Jabatan Notaris}

Pemberian sanksi berupa pemberhentian seorang notaris, dibagi menjadi 3 (tiga) kategori, yaitu:

\section{Pemberhentian Sementara}

Notaris diberhentikan sementara dari jabatannya (Pasal 9 Undang-Undang Jabatan Notaris) karena:

a. Dalam proses pailit atau penundaan kewajiban pembayaran utang

b. Berada dibawah pengampuan

c. Melakukan perbuatan tercela, yaitu melakukan perbuatan yang bertentangan dengan agama, norma kesusilaan dan norma adat (pemberhentian sementara paling lama 6 (enam) bulan.

d. Melakukan pelanggaran terhadap kewajiban dan larangan jabatan (pemberhentian sementara paling lama 6 (enam) bulan.

Sanksi terhadap notaris yang berupa pemberhentian sementara dari jabatannya merupakan tahap lanjutan dari penjatuhan sanksi teguran lisan maupun teguran secara tertulis. Sanksi pemberhentian sementara dari jabatan notaris atau skorsing merupakan masa menunggu pelaksanaan sanksi paksaan pemerintah.

Yang dimaksud dengan pemberhentian sementara notaris dari jabatannya dimaksudkan agar notaris tidak menjalankan tugas jabatannya untuk sementara waktu, sebelum sanksi berupa pemberhentian dengan

10 Penjelasan Pasal 53 Undang-Undang No.30 Tahun 2004 
hormat maupun dengan tidak hormat dijatuhkan kepada notaris. Berdasarkan pasal 80 ayat (1) Undang-Undang Jabatan Notaris, dengan dijatuhkannya sanksi pemberhentian sementara notaris dari jabatannya berarti notaris tersebut telah kehilangan kewenangannya untuk sementara waktu dan notaris tersebut tidak dapat membuat akta apapun. ${ }^{11}$

Hal ini diberlakukan demi melindungi kepentingan publik yang akan menggunakan jasa pelayanan notaris dari perbuatanperbuatan notaris yang dapat merugikan masyarakat atau publik. Selain untuk kepentingan publik, sanksi pemberhentian sementara/skorsing terhadap notaris ini berguna untuk kepentingan pribadi notaris itu sendiri, sehingga notaris lebih berhati- hati, cakap dan cermat dalam membuat akta otentik.

Dari uraian diatas maka sanksi pemberhentian sementara notaris ini diharapkan dapat memberikan rasa kepercayaan masyarakat yang membutuhkan pelayanan jasa notaris akan kepastian hukumnya terhadap pelayanan yang akan di berikan si notaris tersebut, serta sanksi ini sebagai pembatas kebebasan wewenang dari notaris tersebut sehingga notaris lebih mengedepankan sikap teliti dan kehati-hatian dalam menjalankan jabatannya.

\section{Pemberhentian dengan Hormat}

Notaris berhenti atau diberhentikan dari jabatannya dengan hormat (Pasal 8 Undang-Undang Jabatan Notaris) karena: ${ }^{12}$

a. Meninggal dunia

b. Telah berumur 65 (enam puluh lima) tahun

c. Permintaan sendiri

d. Tidak mampu secara rohani dan/atau jasmani untuk melaksanakan tugas jabatan notaris secara terus menerus lebih dari 3(tiga) tahun, yang dibuktikan dengan surat keterangan dokter ahli, atau

e. Merangkap jabatan sebagaimana yang dimaksud dalam Pasal 3 hurf $\mathrm{g}$

\footnotetext{
${ }^{11}$ Fenny Sandra Lisa, SANKSI PEMBERHENTIAN SEMENTARA NOTARIS YANG DINYATAKAN DALAM PROSES PAILIT, Jurnal IImiah Hukum Kenotariatan :Repertorium, Palembang Vol.7 No.2, November 2018, hlm.145

12 Undang-Undang Nomor 30 Tahun 2004
}

Undang-Undang Jabatan Notaris yaitu merangkap jabatan sebagai pegawai negeri, pejabat negara, advokat atau jabatan lain yang dilarang dirangkap dengan jabatan notaris.

Diberhentikan dengan hormat dari jabatan notaris sesuai dengan undang-undang yang berlaku diatas, menunjukan bahwa pemberhentian tersebut diberhentikan secara hormat oleh Menteri atas usul Majelis Pengawas Pusat, dalam hal ini adalah Menteri Hukum dan Hak Asasi Manusia merupakan bentuk sanksi administratif yang menimbulkan akibat hukum berupa hilangnya seluruh kewenangan notaris sehingga tidak dapat menjalankan jabatannya kembali.

\section{Pemberhentian dengan Tidak Hormat}

Notaris sebagai pejabat umum dan diberikan kewenangan secara atributif oleh undang-undang menyebabkan sebagian kedudukannya ada pada lingkup hukum administrasi negara. Dalam melakukan tindakan hukum tersebut, maka pengawasan, pemeriksaan dan penjatuhan sanksi terhadap notaris dilakukan oleh Menteri Hukum dan Hak Asasi Manusia dengan membentuk Majelis Pengawas. Keputusan dalam pemberian sanksi kepada notaris merupakan keputusan dari pemerintah, yang dalam hal ini adalah Menteri Hukum dan Hak Asasi Manusia yang bersifat konkrit dan individual, dimana seperti yang dikutip oleh Philipus M.Hadjon, mendefinisikan keputusan, yaitu: ${ }^{13}$

a. Keputusan menurut undang-undang ini diartikan keputusan tertulis dari suatu organ administratif yang ditujukan pada suatu akibat hukum.

b. Bukan termasuk keputusan dalam arti undang-undang ini adalah suatu keputusan yang mempunyai tujuan umum, suatu tindakan hukum menurut hukum perdata.

Notaris diberhentikan dengan tidak hormat dari jabatannya oleh Menteri atas usul Majelis Pengawas Pusat (Pasal 12 Undang-Undang Jabatan Notaris) apabila: ${ }^{14}$

\footnotetext{
${ }_{13}$ Sukamto Satoto, Pengaturan Eksistensi \& Fungsi Badan Kepegawaian Negara, Offset, Jambi, 2004, hal.215 14 Undang-Undang No.30 Tahun 2004
} 
a. Dinyatakan pailit berdasarkan putusan pengadilan yang telah memperoleh kekuatan hukum tetap.

b. Berada dibawah pengampuan secara terus-menerus lebih dari 3 (tiga) tahun

c. Melakukan perbuatan yang merendahkan kehormatan dan martabat jabatan notaris.

d. Melakukan pelanggaran berat terhadap kewajiban dan larangan jabatan, yaitu tidak memenuhi kewajiban dan melanggar larangan jabatan

e. Dijatuhi pidana penjara berdasarkan putusan pengadilan yang telah memperoleh kekuatan hukum tetap karena melakukan tindak pidan yang diancam dengan pidana penjara 5 (lima) tahun atau lebih.

Sanksi administratif menjadi salah satu pembahasan dalam Undang-Undang Jabatan Notaris dikarenakan bahwa notaris sebagian kedudukannya adalah sebagai pejabat umum yang juga tunduk pada hukum administrasi.

Ada 3 (tiga) alasan dalam Undang-Undang Nomor 30 Tahun 2004 Tentang Jabatan Notaris yang berkaitan dengan alasan pemberhetian notaris dengan tidak hormat dari jabatannya, yang perlu ditafsirkan secara tersendiri agar memperoleh penafsiran yang tepat sesuai dengan karakter jabatan dan akta notaris, yaitu: $:^{15}$

a. Dinyatakan pailit berdasarkan putusan pengadilan yang telah memperoleh kekuatan hukum tetap; yaitu secara tegas dapat ditentukan bahwa kepailitan dan PKPU yang diatur dalam UndangUndang Nomor 30 Tahun 2004 tidak berlaku untuk notaris, karena notaris adalah jabatan, sedangkan menurut Pasal 1 angka 3 UndangUndang Nomor 30 Tahun 2004, bahwa debitor adalah orang (atau badan usaha) yang mempunyai utang karena perjanjian atau undangundang yang pelunasannya dapat ditagih di muka pengadilan. Dalam

15 Habib Adjie, Hukum Notaris Indonesia (Tafsir Tematik terhadap UU.30 Tahun 2004 tentang Jabatan Notaris), Refika Aditama, Surabaya, 2008, hal.65. kapasitas sebagai notaris, tidak dapat notaris berkedudukan sebagai debitor, yang paling sedikit mempunyai 2 (dua) kreditor dan tidak membayar utangnnya yang telah jatuh tempo, kalau secara pribadi (misalnya berdagang atau sebagai pengusaha), seorang notaris juga mempunyai usaha lain dapat saja berkedudukan sebagai debitor dan jika pailit atau melalui PKPU, tetap saja secara pribadi dalam kedudukan sebagai pedagang atau pengusaha saja. Dan notaris dalam menjalankan tugas jabatannya tidak pernah membuat perikatan atau perjanjian utang-piutang dengaan orang atau badan usaha (kreditor).

b. Dijatuhi pidana penjara berdasarkan putusan pengadilan yang telah memperoleh kekuatan hukum tetap karena melakukan tindak pidana yang diancam dengan pidana penjara 5 (lima) tahun atau lebih; yaitu menurut ketentuan Pasal 13 UndangUndang Nomor 2 Tahun 2014 tentang Jabatan Notaris yang menegaskan bahwa notaris diberhentikan dengan tidak hormat oleh Menteri karena dijatuhi pidana penjara berdasarkan putusan pengadilan yang telah memperoleh kekuatan hukum tetap karena melakukan tindakan pidana yang diancam dengan pidana penjara 5 (lima) tahun lebih. Isi pasal ini apakah ancaman (diancam) ditujukan kepada notaris dalam menjalankan tugas jabatannya atau diluar menjalankan tugas jabatannya. Jika dilakukan penafsiran terhadap kata diancam dan dikaitkan dengan kalimat sebelumnya yaitu putusan pengadilan yang telah memperoleh kekuatan hukum tetap, suatu rangkaian kata dan kalimat yang bertentangan. Ancaman meyatakan maksud rencana atau perkiraan, sedangkan suatu putusan yang telah mempunyai kekuatan hukum tetap merupakan suatu putusan yang telah menempuh upaya hukum yang diperkenankan menurut aturan hukum, dan putusan seperti ini wajib untuk dieksekusi oleh jaksa. Maka berdasarkan 
arti ancaman tersebut, bahwa ancaman sebatas maksud perkiraan saja, jadi sebelum sesuatu yang pasti terjadi atau akan dilaksanakan atau belum tentu dihukum dengan pidana penjaraa selama 5 (lima) tahun karena masih berupa ancaman. Dengan demikian jelas telah terjadi pertentangan dalam penerapan kata dalam kalimat dengan istilah yang dipergunakan, yaitu antara penggunaan kata diancam dengan kalimat atau istilah putusan pengadilan yang telah mempunyai kekuatan hukum tetap. Dengan kata lain putusan pengadilan yang telah mempunyai kekuatan hukum tetap bukan merupakan ancaman lagi, tapi sudah merupakan suatu kepastian.

c. Melakukan perbuatan tercela dan perbuatan yang merendahkan kehormatan dan martabat jabatan notaris; yaitu perbuatan notaris yang tersebut dalam Pasal 9 ayat (1) huruf c Undang-Undang Nomor 2 Tahun 2014 Tentang Jabatan Notaris bahwa melakukan perbuatan tercela, yang dalam penjelasannya yang dimaksudkan dengan "melakukan perbuatan tercela" adalah melakukan perbuatan yang bertentangan dengan norma agama, norma kesusilaan, dan norma adat, tidak merupakan alasan untuk memberhentikan sementara notaris dari jabatannya dengan tidak hormat sebagaimana dalam Pasal 12 huruf c Undang-Undang Nomor 2 Tahun 2014 tentang Jabatan Notaris, yaitu melakukan perbuatan yang merendahkan kehormatan dan martabat jabatan notaris, yang dalam penjelasannya yang dimaksudkan dengan perbuatan yang merendahkan kehormatan dan martabat, misalnya berjudi, mabuk, menyalahgunakan narkoba dan berzinah. Dengan adanya perbedaan seperti itu, maka seakan-akan perbuatan notaris yang tersebut dalam Pasal 9 ayat (1) huruf c Undang-Undang Nomor 30 Tahun 2004 Tentang Jabatan Notaris lebih rendah dari ketentuan Pasal 12 huruf c Undang-Undang Nomor 2 Tahun 2014 Tentang Jabatan Notaris, padahal keduanya sama-sama dapat merendahkaan martabat dan jabatan notaris.

Diberhentikan secara tidak hormat oleh Menteri atas usul Majelis Pengawas Pusat, dalam hal ini adalah Menteri Hukum dan Hak Asasi Manusia merupakan bentuk sanksi administratif yang menimbulkan akibat hukum berupa hilangnya seluruh kewenangan notaris sehingga tidak dapat menjalankan jabatannya kembali.

\section{PENUTUP}

\section{A. Kesimpulan}

1. Larangan-larangan bagi pejabat notaris berdasarkan Undang-Undang Nomor 30 Tahun 2004 Tentang Jabatan Notaris terdapat dalam Pasal 17 Undang-Undang Jabatan Notaris yang dapat berupa menjalankan jabatan diluar wilayah jabatannya, meninggalkan wilayah jabatannya lebih dari 7 (tujuh) hari kerja berturut-turut tanpa alasan yang sah, merangkap sebagai pegawai negeri, pejabat negara, dan advokat, sebagai pemimpin atau pegawai badan usaha negara, badan usaha milik daerah, atau badan usaha swasta, sebagai pejabat pembuat akta tanah atau pejabat lelang kelas II diluar tempat kedudukan notaris serta menjadi notaris pengganti.

2. Pelaksanaan sanksi jabatan notaris tidak dijelaskan dalam Undang-Undang No. 30 Tahun 2004, namun dalam Pasal 89 Undang-Undang ini menjelaskan bahwa pada saat undang-undang ini mulai berlaku, kode etik notaris yang sudah ada tetap berlaku sampai ditetapkan kode etik notaris yang baru berdasarkan Undang-Undang Jabatan Notaris, dalam pasal tersebut mengisyaratkan bahwa dalam penerapan sanksi notaris juga termasuk dan berhubungan antara Undang-Undang Nomor 30 Tahun 2004 dan kode etik notaris. Pemberian sanksi berupa pemberhentian seorang notaris, dibagi menjadi 3 (tiga) kategori, yaitu: Pemberhentian Sementara, Pemberhentian dengan Hormat dan Pemberhentian dengan tidak Hormat

\section{B. Saran}


1. Untuk mengangkat harkat dan martabat pejabat notaris haruslah selalu berpegang teguh terhadap aturan dan kode etik notaris serta bertindak adil, jujur, dan tidak berpihak dalam melaksanakan tugas dan tanggung jawabnya.

2. Diperlukan peningkatan mengenai kualitas sumber daya manusia bagi para notaris baik seperti studi banding ataupun pengrekrutan pejabat notaris haruslah memenuhi syarat uji kelayakan bagi para pejabat kenotariatan. Tidak boleh ada kelalaian dalam pemilihan anggota tim dan dewan pengawas untuk menghindari banyaknya anggota terpilih yang tidak memenuhi syarat dan memiliki potensi untuk melakukan sanksi dan melalaikan tugas dan tanggung jawabnya sebagai seorang notaris. Dengan pemberian sanksi dapat menjaga martabat lembaga Notaris, sebagai lembaga kepercayaan, karena jika notaris melakukan pelanggaran, dapat menurunkan kepercayaan masyarakat terhadap Notaris. Undang-Undang Jabatan Notaris (UUJN) yang berisikan ketentuan-ketentuan yang bersifat memaksa atau merupakan suatu aturan hukum yang imperatif untuk ditegakkan terhadap Notaris yang telah melakukan pelanggaran dalam menjalankan tugas jabatannya.

\section{DAFTAR PUSTAKA}

Aditama, Hukum Notaris Indonesia, Jakarta, 2013

Adjie, Habib, Hukum Notaris Indonesia, Tafsir Tematik Terhadap UU No. 30 Tahun 2004 Tentang Jabatan Notaris, Bandung, 2008

Adjie, Habib, Hukum Notaris Indonesia: Tafsir Tematik terhadap UU No.30 Tahun 2004 Tentang Jabatan Notaris, Jakarta, 2007

Adjie, Habib, Hukum Notaris Indonesia (Tafsir Tematik terhadap UU.30 Tahun 2004 tentang Jabatan Notaris), Surabaya, 2008

Adjie, Habib, Sanksi Perdata Dan Administrasi Terhadap Notaris Sebagai Pejabat Publik, Bandung, 2009
Andasasmita, Komar, Notaris Dengan Sejarah, Peranan, Tugas Kewajiban, Rahasia Jabatannya, Bandung, 1981

Anshori, Abdul Ghofur, Lembaga Kenotariatan Indonesia, Yogyakarta, 2009

Bartens, K, Etika, Jakarta, 1994

Cahyadi, Antonius. Manullang, E. Fernando Manullang, Pengantar Ke Filsafat Hukum, Jakarta, 2007

Fahrurrazi. Ramli, Samsul, Bacaan Wajib Swakelola Pengadaan Barang/Jasa, Jakarta, 2014

Fuady Munir, Profesi Mulia (Etika Profesi Hukum bagi Hakim, Jaksa, Advokat, Notaris, Kurator, dan Pengurus), Jakarta, 2005

HR, Ridwan, Hukum Administrasi Negara, Jakarta, 2006 ,Kamus Besar Bahasa Indonesia, Jakarta, 1995

Kie T. Tan, Studi Notariat, Serba-serbi praktek Notaris, Jakarta, 2007

Lisa, S. Fenny, Sanksi Pemberhentian Sementara Notaris yang Dinyatakan Dalam Proses Pailit, Jurnal IImiah Hukum Kenotariatan :Repertorium, Vol.7 No.2, Palembang, 2018

Lubis, K. Suhrawadi, Etika Profesi Hukum, Jakarta, 1994

Lumban Tobing, GHS, Peraturan Jabatan Notaris, Jakarta, 1983

Lumban Tobing, GHS, Peraturan Jabatan Notaris, Jakarta, 1992

Lumban Tobing, GHS, Peraturan Jabatan Notaris (Notaris Reglement), Jakarta, 1999

Mamudji, Sri. Soekanto, Soerjono, Soekanto, Penelitian Hukum Normatif Suatu Tinjauan Singkat, Jakarta, 2004

Mertokusumo, Sudikno, Arti Penemuan Hukum Bagi Notaris, Jakarta, 2004

Muhammad, Abdulkadir, Etika Profesi Hukum, Bandung, 2006

Nico, Tanggungjawab Notaris Selaku Pejabat Umum, Yogyakarta, 2003

Notodisoerjo, R.Soegondo, , Hukum Notariat Di Indonesia, Jakarta, 1993

Nusyirwan, Membedah Profesi Notaris, Bandung, 2000

Pamungkas, Delta, Ensiklopedi Nasional Indonesia, Jakarta, 2004 
Pengurus Pusat Ikatan Notaris, Jati Diri Notaris Indonesia, Dulu, Sekarang Dan Di Masa Datang, Jakarta, 2008

Podewijatna, R. I., Etika (Filsafat Tingkah Laku), Jakarta, 1990

Satoto, Sukamto, Pengaturan Eksistensi \& Fungsi Badan Kepegawaian Negara, Jambi, 2004

Shidarta, Moralitas Profesi Hukum (Suatu Tawaran Kerangka Berpikir), Bandung, 2009

Soemoatmodjo, Soetarjo, Apakah Notaris, PPAT, Pejabat Lelang, Yogyakarta, 1986

Soeroso, R., Pengantar IImu Hukum, Jakarta, 2006

Soesanto, R., Tugas, Kewajiban dan Hak-Hak Notaris, Wakil Notaris, Jakarta, 1982

Tirtaamidjaya, H. M., Pokok-Pokok Hukum Pidana, Jakarta, 1995

Widyadharma, Ignatius Ridwan, Hukum Profesi tentang Profesi Hukum, Semarang, 1994

\section{PERATURAN PERUNDANG-UNDANGAN}

Kitab-Kitab Hukum Pidana

Pedoman Resmi UUD 1945

Undang-Undang Dasar 1945

Undang-Undang No.30 Tahun 2004

Undang-Undang No.5 Tahun 1986

\section{Website}

http://repository.usu.ac.id/bitstream/handle/1 23456789/66615/Chapter\%20II.pdf? sequence $=3 \&$ is Allowed $=y$

http://repository.usu.ac.id/bitstream/handle/1 23456789/66615/Chapter\%20ll.pdf? sequence $=3 \&$ isAllowed $=y$

http://repository.umy.ac.id/bitstream/handle/ 123456789/12209/6.\%20BAB\%20II. pdf?sequence $=4 \&$ isAllowed $=y$

http://repository.ump.ac.id/3369/3/Bab\%20II Alif\%20Nur\%20Choliq.pdf

http://repository.unissula.ac.id/9764/5/BAB\%2 0l 1.pdf

http://id.wikipedia.org/wiki/Notaris\#prosedur pengangkatan notaris sesuai deng an UUJN

https://media.neliti.com/media/publications/2 42466-sanksi-hukum-terhadapnotaris-yang-melan-a6f743e3.pdf http://lib.ui.ac.id/file?file=digital/130992T\%2027422-

Pengawasan\%20majelis-Analisis.pdf

https://birojasanotaris.com/infonotaris/larangan-jabatan-notarismenurut-uujn-pasal-17/ 